\title{
УДК 316.334.
}

\section{DOI: 10.24144/2218-5348.2020.1(21).107-117}

\author{
Наталія Варга, \\ кандидат соиіологічних наук, доцент кафедри \\ сочіологї та сочзіальної роботи \\ ДВНЗ «Ужггородський національний університет»
} (м. Ужсгород, Украӥна)

\section{ТРУДОВА МІГРАЦІЯ В ЗАКАРПАТТІ (НА ОСНОВІ ОПИТУВАННЯ СТУДЕНТІВ)}

Статтю присвячено дослідженню та аналізу міграційних настроїв студентів. "Фасадність» демократи, загальна неефективність економіки, зниження рівня культури й освіти в суспільстві, корупція, кримінальний капіталізм, «олігархічна» концепція управління - все це стає виштовхуючими факторами (push-factors), які зумовлюють міграчійні настрої чи від’їд молоді з вищуою і постуніверситетською освітою. Виходячи із результатів дослідження, зазначимо, щуо траєкторія професійних планів респондентів спрямована у напрямі зовнішньої трудової мігращії, щзо негативно позначиться на економічному розвитку регіонів у зв'язку з втратою перспективного трудового ресурсу.

Ключові слова: студенти, еміграційні настрої, міграція, прачевлаштування

The article is devoted to the research and analysis of the migratory moods of students of higher education institutions during studies as an important factor of their life prospects. In recent years, Central and Eastern Europe has been experiencing particularly acute problem of labor migration processes that are going in one direction. Young working population is leaving the country and is not coming back. It should be noted that such a vector of economic migration is always directed from the periphery towards the center, and from developing to more economically developed countries.

At present, there is an intensification of migration processes in the world, and these processes increasingly involve the population with high level of human capital (people with university and post-university education). In the scientific literature, this process is referred to as "elite migration" and implies mass migration of highly skilled professionals, which is associated with an increase in the role of multinational corporations and, consequently, a decrease in the role of the national economy in the global economy. 
Countries that are interested in "brain gain" and know their economic cost are pursuing an active and purposeful migration policy to attract highly qualified specialists from developing countries.

The purpose of the article is to carry of the migratory moods of higher education institutions in Central and Eastern Europe as an important factor of their life prospects. Because of the special political, social and economic situation in Ukraine caused by the conflicts in the Eastern regions of the country and the economic crisis the study puts more emphasis on Ukraine.

According to expert estimates, migration of individuals with high level of social capital is determined not only by social and economic problems that are characteristic of countries in a transitional economy, but also by political and sometimes cultural factors. Often, the migration of the social elite is a response to the systemic crisis that these countries are experiencing in the process of democratic formation. Facade democratic regime, the general inefficiency of the economy, the decline in the level of culture and education in society, as well as the lack of clear prospects, all become push-factors that determine the departure of such individuals.

We characterized the migratory moods in the context of possible emigration, identified and compared the prerequisites and motives of the students' paid and volunteer work, as well as found the connection between the students' field of study and their type of work. Based on the results of the research, we can state that the respondents' professional plans are directed towards external labor migration, which will negatively affect the economic development of the regions due to the loss of promising workforce.

Keywords: students, migratory moods, emigration, migration, employment.

Враховуючи особливості географічного розташування Закарпатської області (область межує 3 чотирма європейськими країнами: Румунією, Угорщиною, Словаччиною, Польщею), економічну ситуацію та надлишковість у межах області незайнятих трудових ресурсів, можна визначити, що одним із вагомих важелів регулювання місцевого ринку праці Закарпаття $\epsilon$ міжнародна трудова міграція населення. Припущеннями $\epsilon$, що війна 3 Російською Федерацією, переселення великої кількості громадян із Донбасу в інші області України, ознаки етнополітичної нестабільності, велика кількість жителів, які володіють подвійним громадянством (угорським зокрема), зниження життєвого рівня українців, отже, очікувана хвиля трудової і - додаймо - освітньої міграції у країни $Є С$, сприятимуть зростанню міграційних потоків 3 території регіону. Тим більше, що немає підстав стверджувати про припинення діяльності каналів нелегальної міграції громадян азійських країн, що проходять через територію Закарпатської області. В останні роки питання трудової міграції із Закарпаття набуває ознак національної небезпеки. Скасування безвізового режиму з рядом країн 
Свропейського Союзу привело до масової, прихованої трудової міграції українців $[1,2]$.

Запорукою розвитку і добробуту будь-якої країни є високий рівень людського капіталу (молодь з вищою і постуніверситетською освітою). У статті ми проаналізували чинники життєвих перспектив - міграційні настрої та тимчасову зайнятість студентів під час навчального процесу, які мають вагомий вплив на те, чи залишиться завтра досвідчена молодь вдома, чи покине свою країну назавжди, що стане причиною зниження рівня життя i потенційних можливостей для розвитку.

Мета - визначити напрями трудової міграції в Закарпатті на основі опитування студентів.

Для детального вивчення причин, обставин, що спонукають молодих людей до виїзду за кордон, було проведено опитування студентської думки, оскільки саме молоде покоління зараз стоїть на шляху до побудови власного, стабільного життя. З'ясовували наміри щодо міграції молодого населення України за кордон. Загалом було опитано близько 300 студентів Ужгородського національного університету, 54\% осіб жіночої статі та 46\% p - чоловічої. Це студенти 2-3 курсів різних факультетів.

Загалом дані засвідчили, що соціально-економічна ситуація в країні дедалі загострюється. Це особливо відчутно в економічній площині, бо більшість проблем, 3 якими щодня стикаються громадяни України, не вирішена, тож їх життя повсякчас погіршується. Аналіз відповідей респондентів показав, що в країні склалася напружена ситуація щодо стабільності та забезпеченості. Абсолютна більшість опитаних висловила своє позитивне ставлення до виїзду за кордон.

\section{Ставлення студентів до виїзду за кордон}

Діаграма 1

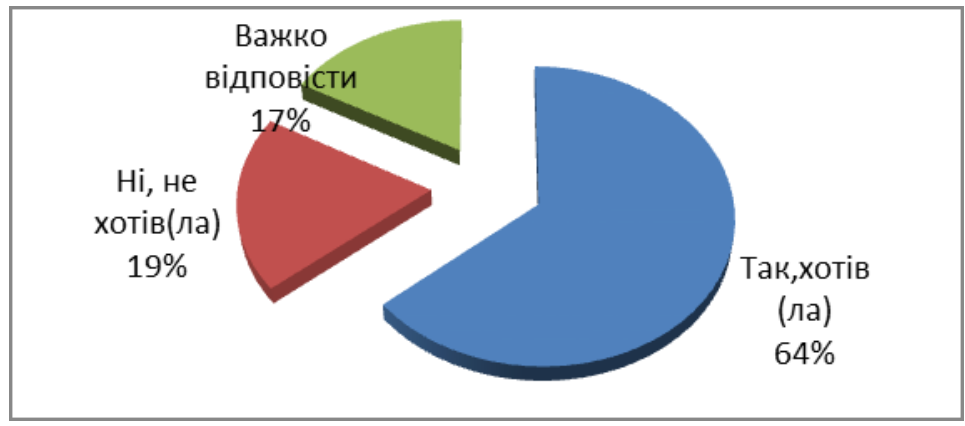

Переважна частина опитуваних прагне виїхати за кордон (64\%), лише $19 \%$ хотіли б залишитися на рідних теренах та $17 \%$ респондентів вагалися. Як бачимо, більшість опитаних мають велике бажання виїхати за кордон через власні, переважно матеріальні потреби, тому дуже маленький відсоток все ж таки бажає залишитись в країні. 


\section{Класифікація видів трудової міграції}

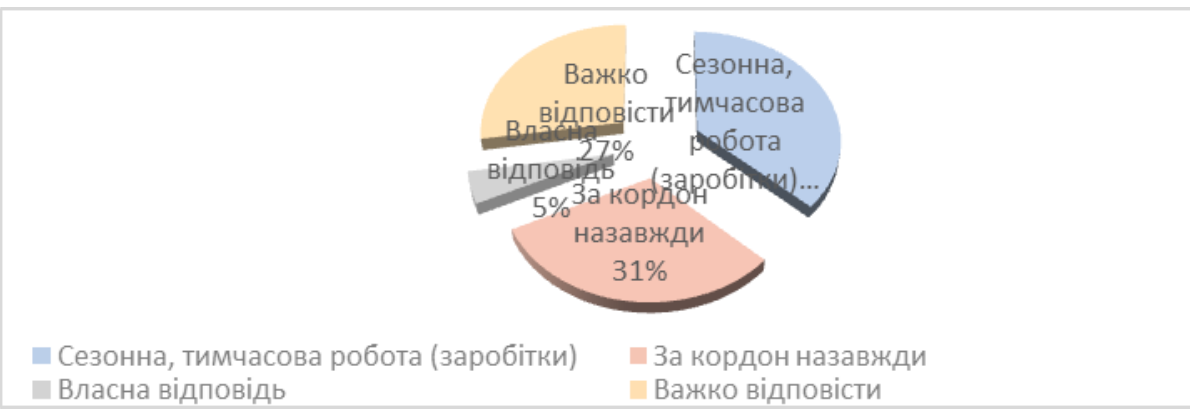

Отже, можна зробити висновок, що більшість студентів вважають, що причинами збільшення емігрантів в найближчий час $\epsilon$ нестабільність в Україні, високий рівень безробіття та безперспективність.

Наші студенти прагнуть виїжджати за кордон на роботу та навчання через нестабільний і несприятливий соціально-економічний клімат в Україні.

Основними факторами, що впливають на відтік людських ресурсів є: нестабільність в країні, відсутність перспектив та неврегульована політика. Наприклад, вища в 5-10 разів заробітна плата в інших країнах приваблює низькокваліфіковану робочу силу.

Таблиия 1

Розподіл відповідей на запитання: «Скажи, Ти особисто хочеш виїхати з країни»?

(\% до числа опитаних)

\begin{tabular}{|l|l|}
\hline Так, хотів (ла) & 63,6 \\
\hline Нi, не хотів (ла) & 19,0 \\
\hline Важко відповісти & 16,8 \\
\hline
\end{tabular}

Таблиия 2

Розподіл відповідей на запитання: «Якщо планусш виїжджати за кордон, то це буде....,» (\% до числа опитаних)

\begin{tabular}{|l|c|}
\hline Сезонна, тимчасова робота (заробітки) & 36,8 \\
\hline За кордон назавжди & 31,0 \\
\hline Власна відповідь & 4,7 \\
\hline Важко відповісти & 27,5 \\
\hline
\end{tabular}


Близько 56,2\% отримують освіту, вивчають мову, а в майбутньому все ж таки планують виїжджати за кордон. Цей ризик еміграції готового спеціаліста, який буде працювати на користь іншої держави, може привести до песимістичних наслідків.

Таблиия 3

Розподіл відповідей на запитання: «Що Ти робиш для того, щоб виїхати за кордон»?

(\% до числа опитаних)

\begin{tabular}{|l|c|}
\hline Заробляю, накопичую гроші & 13,6 \\
\hline Отримую освіту, вивчаю мову & 56,2 \\
\hline $\begin{array}{l}\text { Відновлюю зв'язки з родичами, знаходжу } \\
\text { друзів, знайомих за кордоном }\end{array}$ & 7,2 \\
\hline Оформляю документи & 13,2 \\
\hline Інше & 2,3 \\
\hline Важко відповісти & 7,5 \\
\hline
\end{tabular}

Відповіді студентів на запитання «Чому Ти думаєш, що в найближчий час кількість людей, що назавжди виїдуть за кордон, буде збільшуватися?», можна узагальнити так: $35 \%$ вважають, що збільшення емігрантів в найближчий час пов'язане 3 нестабільністю в країні, відсутністю перспектив та неврегульованою політикою. Частка тих, хто вважає, що збільшення емігрантів пов'язана 3 низьким рівнем життя, бідністю, безробіттям та інфляцією, становить $32 \%$. Проте $23 \%$ студентів, вважають, що за кордоном життя краще і є більше можливостей для самореалізації. Частка тих, хто вважає, що з'явилось більше можливостей виїхати, побачити нове життя, становить 9\%. Частка студентів, які не змогли відповісти на це запитання, становить $1 \%$.

Таблиия 4

Розподіл відповідей на запитання: «Чому в майбутньому Ти хочеш залишити рідну місцевість»? (\% до числа опитаних)

\begin{tabular}{|l|c|}
\hline Немає роботи & 31,5 \\
\hline Немає перспектив на майбутнє & 62,4 \\
\hline Немає можливості професійного розвитку & 28,8 \\
\hline Немає можливості особистісного розвитку & 14,8 \\
\hline Погана атмосфера & 4,8 \\
\hline
\end{tabular}




\begin{tabular}{|l|c|}
\hline Немає розваг, нудьга & 7,7 \\
\hline Низькі заробітки & 54,4 \\
\hline Панує провінційність & 5,2 \\
\hline Недостатньо шансів на належний рівень життя & 33,9 \\
\hline Так робить багато знайомих & 4,4 \\
\hline Інше & 0,3 \\
\hline
\end{tabular}

Серед напрямів еміграції переважає західний, причому країни близького зарубіжжя (Чехія, Угорщина, Словаччина, Польща) та країни Західної Європи (Франція, Великобританія, Німеччина, Іспанія), де $\epsilon$ можливість легалізації свого статусу.

Таблиия 5

Розподіл відповідей на запитання:

«Якщо плануєш виїжджати, то в які країни саме»? (\% до числа опитаних)

\begin{tabular}{|l|c|}
\hline Країни Східної Свропи (Чехія, Угорщина, Словаччина, Польща) & 36,7 \\
\hline $\begin{array}{l}\text { Країни Західної Свропи (Франція, Великобританія, Німеччина, } \\
\text { Іспанія) }\end{array}$ & 29,7 \\
\hline Країни СНД (Росія, Білорусь, Молдова) & 2,8 \\
\hline Країни Балтії (Латвія, Литва, Естонія) & 0,3 \\
\hline $\begin{array}{l}\text { Країни далекого зарубіжжя (Південна/Північна Америка, } \\
\text { Австралія, Канада) }\end{array}$ & 13,8 \\
\hline Важко відповісти & 83,2 \\
\hline
\end{tabular}

Головними стимулами до еміграції є матеріальні фактори, а саме: пошук заробітків $(77,2 \%)$, самореалізація та краще життя $(60,0 \%)$, соціальна несправедливість у країні (корупція, нестабільність).

Таблиия 6

Розподіл відповідей на запитання:

«Як Ти вважаєш, чому сьогодні люди виїжджають за кордон на довгий термін?

(\% до числа опитаних)

\begin{tabular}{|l|l|}
\hline Соціальна несправедливість в країні (корупція, нестабільність) & 49,5 \\
\hline В пошуках роботи, заробітків & 77,2 \\
\hline Побачити світ, інших людей, культури & 29,8 \\
\hline
\end{tabular}




\begin{tabular}{|l|l|}
\hline Для освіти, підвищення кваліфікації & 23,7 \\
\hline Для самореалізації, кращого життя & 60,0 \\
\hline Важко відповісти & 3,4 \\
\hline
\end{tabular}

Серед найпоширеніших видів економічної діяльності трудових мігрантів, на думку опитаних студентів, є низькокваліфікована робота, яка може і не вимагати наявності освіти, будівництво $(79,9 \%)$, промисловість: завод, фабрика $(54,6 \%)$, робота домашньої прислуги (52,9\%). В той же час за спеціальністю, яку здобувають, планують працювати лише 17,8\%.

Таблиия 7

\section{Види економічної діяльності трудових мігрантів}

(\% до числа опитаних)

\begin{tabular}{|l|l|}
\hline Будівництво & 79,7 \\
\hline Робота домашньої прислуги & 52,9 \\
\hline Оптова й роздрібна торгівля & 14,2 \\
\hline Сільське господарство & 27,4 \\
\hline Промисловість (завод, фабрика) & 54,6 \\
\hline Робота за спеціальністю, яку здобуваєш & 17,8 \\
\hline Інше & 0,3 \\
\hline Важко відповісти & 7,3 \\
\hline
\end{tabular}

Знову ж таки, серед можливостей трудової міграції переважає матеріальний фактор, а саме: забезпечення добробуту своєї сім’ї - 81,8\% та підвищення кваліфікації працівників, переймати досвід інших країн $-42,5 \%$. Аналізуючи перспективи трудових переміщень населення, висновки невтішні. Якщо серед молодих людей переважають еміграційні орієнтації, то це приводить до втрати найбільш економічного та соціально-активного прошарку населення. В майбутньому це приведе до значної депопуляції населення, старіння нації. 
Розподіл відповідей на запитання: «На Твою думку, трудова міграція дає можливість...»

(\% до числа опитаних)

\begin{tabular}{|l|l|}
\hline Забезпечити добробут своєї сім’ї & 81,8 \\
\hline Зменшити напруженість на ринку праці, подолання безробіття & 21,2 \\
\hline $\begin{array}{l}\text { Сприяти валютним надходженням від трудових мігрантів, що } \\
\text { інвестуються в економіку країни }\end{array}$ & 20,0 \\
\hline $\begin{array}{l}\text { Підвищувати кваліфікацію працівників, переймати досвід інших } \\
\text { країн }\end{array}$ & 42,5 \\
\hline $\begin{array}{l}\text { Здійснювати тимчасову міграцію як альтернативу виїзду на постійне } \\
\text { місце проживання }\end{array}$ & 37,8 \\
\hline Не дає ніяких можливостей & 6,8 \\
\hline
\end{tabular}

Матеріальне збагачення в той же час приводить до ризиків для трудових мігрантів, серед яких переважають незнання мови в країні перебування - 71,3\%, нелегальний і неофіційний статус трудового мігранта $63,6 \%$, негідні умови праці, недоплата - 45,4, незнання законів в країні перебування - 42,9\%. Деякі дослідники взагалі говорять про використання трудових мігрантів як рабсили. Ризики втрати здоров'я, працездатності, а деколи і життя переважають над матеріальною мотивацією у більшості трудових мігрантів.

Таблиия 9

\section{Основні небезпеки або загрози, з якими може стикнутися мігрант}

(\% до числа опитаних)

\begin{tabular}{|l|l|}
\hline Важко знайти роботу & 45,4 \\
\hline Незнання мови в країні перебування & 71,3 \\
\hline Торгівля людьми, негідні умови праці, проживання, недоплата 3/п & 45,4 \\
\hline Незнання законів у країні перебування & 42,9 \\
\hline Оформлення легального перебування і працевлаштування & 63,6 \\
\hline Інше & 0,9 \\
\hline
\end{tabular}

Проаналізувавши отримані відповіді, можна зробити висновок, що більшість студентів нашого університету вважає, що в основному від'іжджають за кордон ті, в кого є можливість (27 \%). Другою категорією людей, які найчастіше емігрують за кордон, є ті, в кого за кордоном родичі, 
друзі, зв'язки (18\%). На третій позиції серед людей, які найчастіше покидають країну, студенти виділили людей певних професій (вчені, творчі люди, спеціалісти), їхня частка становить 17\%. Проте серед людей, які покидають країну, є бідні, розчаровані і ті, хто не може самореалізуватись в Україні (16 \%). Студенти вважають, що 13 \% людей, які виїжджають 3 України, становлять розумні, освічені, талановиті інтелігентні люди. Серед тих, хто найменше емігрує, студенти виділили, категорію багатих людей, тих, хто має гроші, їхня частка становить 9\%. Причиною таких невтішних результатів є економічна нестабільність в Україні, низький рівень життя та соціальна незахищеність громадян.

Табличя 10

\section{Основні категорії людей, залучених до трудової міграції}

(\% до числа опитаних)

\begin{tabular}{|l|l|}
\hline Багаті люди, у кого є гроші & 21,4 \\
\hline Люди певних професій (вчені, творчі люди, спеціалісти) & 40,4 \\
\hline Розумні, освічені, талановиті, інтелігенція & 32,1 \\
\hline Бідні, розчаровані, хто не може самореалізуватись в Україні & 38,8 \\
\hline Різні, в кого є можливість & 64,5 \\
\hline В кого є родичі, знайомі, зв'язки & 41,9 \\
\hline Інше & 25,0 \\
\hline
\end{tabular}

Головними причинами, еміграції за кордон є саме нестабільність в країні, неврегульована політика в державі - 79,6\% та низький рівень життя, бідність, інфляція, безробіття - 72,8\%.

Табличя 11

Розподіл відповідей на запитання: «Чому кількість людей, що назавжди їдуть за кордон, буде збільшуватись»?

(\% до числа опитаних)

\begin{tabular}{|l|l|}
\hline Через нестабільність у країні, неврегульовану політику & 79,6 \\
\hline За кордоном життя краще, більше можливості самореалізації & 53,4 \\
\hline Через низький рівень життя, бідність, безробіття, інфляцію & 72,8 \\
\hline 3'явилось більше можливостей виїхати, побачити інше життя & 20,4 \\
\hline Важко відповісти & 5,0 \\
\hline
\end{tabular}


Можна зробити висновок, що міграція серед студентів, з одного боку, - це досить позитивно, але в той же час настрої серед опитаних студентів досить песимістичні. Якщо молоді люди, навчаючись в університеті, все ж не пов'язують своє майбутнє з цією країною, то варто приймати ці тенденції до уваги.

Запорукою розвитку і добробуту будь-якої країни є високий рівень людського капіталу (молодь 3 вищою і постуніверситетською освітою). У статті ми проаналізували чинники життєвих перспектив - міграційні настрої та тимчасову зайнятість студентів під час навчального процесу, які мають вагомий вплив на те, чи залишиться завтра досвідчена молодь вдома, чи покине свою країну назавжди, що стане причиною зниження рівня життя i потенційних можливостей для розвитку.

\section{Список використаних джерел:}

1. Бурдельный, Е. (2011). Современное состояние трансграничных международных миграций: Moldoscopie (Проблемы политического анализа), nr.3 (LIX), 2011. Кишинев: USM, C. 115-128.

2. Baranyi Bela. (2005). A Spreading Europe: New Challenges to HungarianUkrainian Cross-border Cooperation. Eurointegration Challenges in Hungarian-Ukrainian economic relations. Budapest.

3. Андерсон, А.В. (2013). Шмыткова. Типологизация приграничных регионов украины на основе евроинтеграционного признака с особым акцентом на украинско-венгерское пограничье. Вестник ТГУ, Т.18, Вып.2

4. Либанова Э., Позняк А. (2012). Формирование потоков трудовых миграций в приграничных регионах Украины. Миграция и пограничный режим: Беларусь, Молдова, Россия и Украина. Сб. научных трудов., К. C. $124-144$.

5. Хаджімануел, Т., Малиновська, О., Мошняга, В., Шахотко, Л. (2007). Огляд трудової міграції в Україні, Молдові, Білорусії. Міжнародна організація з міграції., К., Представництво МОМ в Україні. - С. 10.

\section{REFERENCES}

1. Burdel'nyy, Ye. (2011). Sovremennoye sostoyaniye transgranichnykh mezhdunarodnykh migratsiy [The Current State of Cross-border International Migration]. Moldoscopie (Problemy politicheskogo analiza) - Moldoscopie (Problems of Political Analysis), 3(LIX), 115-128. Kishinev: USM [in Russian].

2. Baranyi, B. (2005). A Spreading Europe: New Challenges to HungarianUkrainian Cross-border Cooperation. Eurointegration Challenges in Hungarian-Ukrainian economic relations. Budapest [in English].

3. Anderson, A.V. (2013). Shmytkova. Tipologizatsiya prigranichnykh regionov ukrainy na osnove yevrointegratsionnogo priznaka s osobym aktsentom na ukrainsko-vengerskoye pogranich'ye[Shmytkova. Typologization of the border 
regions of Ukraine on the basis of the European integration criterion with special emphasis on the Ukrainian-Hungarian borderland]. Vestnik TGU-Bulletin of TSU, (Vols.18), 2 [in Russian].

4. Libanova, E., Poznyak, A. (2012). Formirovaniye potokov trudovykh migratsiy $\mathrm{v}$ prigranichnykh regionakh Ukrainy [The formation of labor migration flows in the border regions of Ukraine]. Migratsiya $i$ pogranichnyy rezhim: Belarus', Moldova, Rossiya i Ukraina - Migration and border regime: Belarus, Moldova, Russia and Ukraine, 124-144 [in Russian].

5. Khadzhimanuel, T., Malynovs'ka, O., Moshnyaha, V., \& Shakhotko, L. (2007). Ohlyad trudovoyi mihratsiyi v Ukrayini, Moldovi, Bilorusiyi [Review of labor migration in Ukraine, Moldova, Belarus]. Kyiv, Predstavnytstvo MOM v Ukrayini - IOM Representation in Ukraine, p.10 [in Ukrainian]. 